
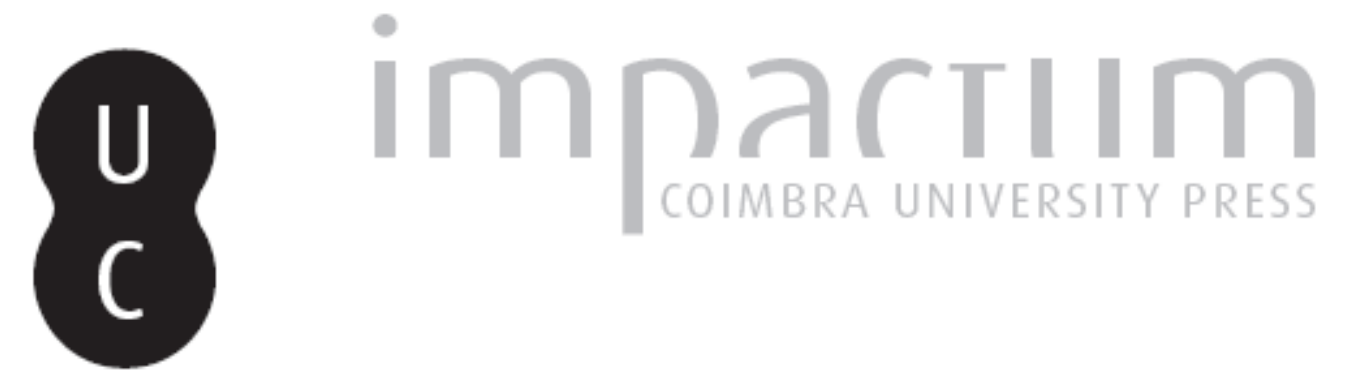

\title{
[Recensão a] Enrique Cerrillo Martin de Cáceres, La vida rural romana en Extremadura
}

\author{
Autor(es): D'Encarnação, José
}

Publicado por: Imprensa da Universidade de Coimbra

URL persistente:

URI:http://hdl.handle.net/10316.2/45623

DOI:

DOI:https://dx.doi.org/10.14195/1647-8657_25_17

Accessed : $\quad$ 26-Apr-2023 08:09:27

A navegação consulta e descarregamento dos títulos inseridos nas Bibliotecas Digitais UC Digitalis, UC Pombalina e UC Impactum, pressupõem a aceitação plena e sem reservas dos Termos e Condições de Uso destas Bibliotecas Digitais, disponíveis em https://digitalis.uc.pt/pt-pt/termos.

Conforme exposto nos referidos Termos e Condições de Uso, o descarregamento de títulos de acesso restrito requer uma licença válida de autorização devendo o utilizador aceder ao(s) documento(s) a partir de um endereço de IP da instituição detentora da supramencionada licença.

Ao utilizador é apenas permitido o descarregamento para uso pessoal, pelo que o emprego do(s) título(s) descarregado(s) para outro fim, designadamente comercial, carece de autorização do respetivo autor ou editor da obra.

Na medida em que todas as obras da UC Digitalis se encontram protegidas pelo Código do Direito de Autor e Direitos Conexos e demais legislação aplicável, toda a cópia, parcial ou total, deste documento, nos casos em que é legalmente admitida, deverá conter ou fazer-se acompanhar por este aviso.

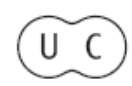


FACULDADE DE LETRAS

INSTITUTO DE ARQUEOLOGIA

CONIMBRIGA

$V O L U M E X X V$

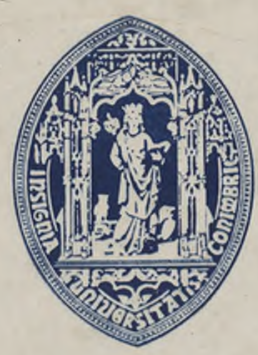

UNIVERSIDADE DE COIMBRA

1986 
Na página 234, Scallabis é classificada município cesariano: seria, de preferência, uma colónia, como Pax Iulia (que não é citada). O mapa das fábricas de salga em Hispânia e na Mauritânia Tingitana (p. 252) retirado da obra de M. Ponsich e M. Tarradell (1965), teria necessitado de actualização, até porque traz, no que se refere ao litoral português, muitos erros nas designações toponímicas e na sua localização. Cita-se F. Bajo como autor do mapa da pág. 270 - mas não vimos qualquer obra sua referida na bibliografia que, por ordem alfabética de autores, complementa o volume. Aliás, apresenta-se também: uma tábua de abreviaturas e siglas; uma cronologia comparada dos feitos políticos e militares, e dos dados económicos e sociais com os factos da história geral romana.

Facilitam a consulta os índices: onomástico, toponímico, de mapas, geral.

RAQUEL VILAÇA

JosÉ D'ENCARNAÇÃO

Enrique Cerrillo Martin de Cáce res, La vida rural romana en Extremadura.

Servido de Publicaciones de la Universidad de Extremadura. Cáceres, 1984. 148 p., ilustrado. [I.S.B.N.: 84-600-3711-8].

Não se trata de um livro sobre a vida quotidiana dos agricultores romanos nem de um manual de arqueologia rural. É, sobretudo, uma história da agricultura na Estremadura espanhola; um primeiro ensaio de síntese do que se sabe, os problemas que se levantam à investigação, as hipóteses de os resolver. Uma reflexão levada a cabo pelo autor como membro da equipa que, no Departamento de Pré-História e Arqueologia da Universidade de Extremadura, tem como um dos seus objectivos científicos procurar explicar, sem tabus, sem preconceitos e sem complexos de inferioridade, «a vida campesina e os comportamentos agrários fortemente arraigados na região e ainda hoje nela vigentes» (p. 13).

Em linguagem acessível, E. Cerrillo mostra, no I capítulo (p. 19-45), como, desde os tempos pré-históricos, se originou a exploração agrária na Estremadura. O II capítulo aborda as fases da romanização e as transformações paulatinas que ela foi introduzindo: os primeiros estabelecimentos rurais romanos (p. 52-65), a partir dos limites mais afastados dos termos urbanos, e a segunda fase da ocupação rural que já supõe «um autêntico ordenamento territorial» (p. 75).

No cap. Ill, Os Sítios (p. 81-126), E. Cerrillo não apresenta, como o título poderia fazer supor, um catálogo das villae estremenhas ou a sua caracterização arquitectónica individualizada. Aproximando-se muito embora de um esquema descritivo de tipo arqueológico, começa por referir os factores que levavam à escolha da localização das villae (por exemplo, as caracte- 
rísticas dos quatro elementos — ar, água, terra e trabalho - como diz Paládio), para descrever depois «as esferas de actividades nos assentamentos rurais romanos» (p. 88-103), «a produção agrária» (p. 103-108), «proprietários, servos e colonos» (p. 108-119) e terminar com uma panorâmica sobre a introdução do Cristianismo (p. 119-126) que, em seu entender, poucas ou nenhumas transformações acarretou à vida agrária:

«O Cristianismo - escreve E. Cerrillo - não quebrará os moldes tradicionais do campo, já que precisamente os três produtos básicos do cultivo — trigo, vinha e oliveira - serão, até certo ponto, sacralizados mediante a sua utilização simbólica como pão e vinho na missa e óleos para as unções» (p. 124).

Livro de bolso, La vida rural romana en Extremadura é ilustrado com desenhos elucidativos e o Autor utiliza muitas vezes as páginas da direita para incluir (em lugar das notas infrapaginais) textos referentes aos temas em análise, boa parte deles retirados dos agrónomos latinos. Cumpre, pois, em nosso entender, a finalidade que se propôs: apresentar uma primeira síntese acerca das questões levantadas pela agricultura peninsular ao tempo dos Romai os. Não respondendo - porque não era essa, aliás, a intenção — à problemática teórica em tempos sistematizada por Jorge Alarcão para uma zona, o Alentejo, bastante semelhante à Estremadura espanhola (Sobre a economia rural do Alentejo na época romana, «Conimbriga», XV, 1976, p. 5-44), resposta que, de resto, só a escavação total e sistemática de uma villa pode fornecer - como esperamos venha a fornecer a que se levou a efeito em S. Cucufate (Vidigueira) — o Autor soube evitar a tentação (assaz frequente) de acumular dados sobre dados, para privilegiar a reflexão globalizante que leva em linha de conta não somente os testemunhos arqueológicos mas que, ao invés, os interpreta à luz dos dados antropológicos e etnográficos - para uma verdadeira etnoarqueologia da vida rural (cap. IV — p. 129$-135)$.

JOSÉ D'ENCARNAÇÃO

Jaime SıLes, Epigrafia Hispanica - Léxico de Inscripciones Ibéricas. Ministério de Cultura, Madrid, 1985, 437 p.

$\mathrm{Na}$ Introdução, preconiza Jaime Siles a transformação da filologia clássica numa filologia clássica peninsular, cujos objectivos seriam: a decifração e caracterização das escritas tartéssicas e bástulo-turdetanas, do alfabeto grego-ibérico, do celtibérico, do alfabeto monetário «líbio-fenício» e da língua lusitana. Interessaria, ainda, considerar a integração do aquitano no contexto linguístico peninsular, «delimitar as áreas linguísticas à luz das fontes clássicas e dos documentos epigráficos e monetários». Por fim, numa perspectiva globalizante, tais análises deverão inserir-se nos estudos, de carácter mais amplo, de onomástica. 